

\title{
The Problem of the Authenticity of African Fairy Tales using the Examples of the Fairy Tales of the Fon from Benin and the "Kinder und Hausmärchen" of the Brothers Grimm
}

\author{
Sewanou M. J. Lanmadousselo \\ Université de Parakou, Faculté des Lettres, Arts et Sciences Humaines \\ E-mail: jupitomartio@yahoo.fr
}

\begin{abstract}
This contribution deals with the question of foreign influences on the Fon fairy tales from Benin (West Africa). It has endeavoured to answer the question whether the similarities found in some Fon fairy tales that have been handed down until now and in some Grimm's fairy tales that have been written down since the $19^{\text {th }}$ century have an effect on the authenticity of the former. It shows that at the centre of the similarities between fairy tales from different cultures is the human being himself through his mental disposition as a producer of the same or similar fairy tales.
\end{abstract}

Keywords: foreign influences, Fon fairy tales, Grimm's fairy tales, similarities, authenticity, human being 


\section{Introduction}

The question of foreign influences on the Fon fairy tales or on the Beninese folktales is related to the strong similarities between some African fairy tales and European fairy tales. As early as the $19^{\text {th }}$ century, the similarities of fairy tales from culturally different regions had already attracted the interest of fairy tales collectors and researchers. In their collecting activities for example, the Brothers Grimm noted many similarities between their fairy tales and other European fairy tales (Cf. Lanmadousselo 2021, p. 184). From 1999 onwards, Schmidt (Schmidt 1999), Wekenon Tokponto (Wekenon Tokponto 2003) and Aglewe (Aglewe 2015), who undertook a comparative study between Grimm's and African fairy tales, make the same observations: that some fairy tales are similar in both the African as well as in the German or European repertory. In an interview, the German folklorist Sabine Wienker-Piepho (WienkerPiepho 2017) reported that she had found a variant of "Rotkäppchen" (Eng.: "Little Red Riding Hood"; Children's and Household tale 26) in the Madagascan fairy tales repertory. Some of the fairy tales I have collected, albeit with different specifics, also show similarities to the Grimm fairy tales (Cf. Lanmadousselo 2021, p. 184). Thus the similarities of some Fon tales with the European ones raises the question of their authenticity or origin, for example, whether European tales did not migrate and influence the Fon volumes.

\section{Concrete example cases of similarities between some Fon fairy tales and some Grimm's fairy tales}

Many Fon fairy tales have similarities with some Grimm fairy tales. In the Fon fairy tale Die zwei Jägersöhne (Eng.: "The hunter's sons"; cf. Lanmadousselo 2021, pp. 309-313), for example, a hunter's son goes hunting one day and observes ghosts called Aziza opening a termite mound by means of a spell and taking money from inside. The latter goes to the termite mound on a day when the ghosts, who live there are absent, and fetches a lot of money using the spell "Termite mound, open!" and "Termite mound, close!". The hunter's son told his brother about the termite mound. Both brothers get caught by the azizas in further attempts and are killed. Also in the Grimm's fairy tale, Simeliberg (Children's and Household tale 142), a mountain appears which has almost the same characteristic of the termite mound in the Fon fairy tale. In this fairy tale, there is talk of a large and bare mountain that is the source of riches (silver, gold, pearls and precious stones). It belongs to twelve wild great men who have the right entrance and exit formula: "Berg Semsi, Berg Semsi, tu dich auf" (Eng.: "Mountain Semsi, mountain Semsi, open up") and "Berg Semsi, Berg Semsi, tu dich zu" (Eng.: "Berg Semsi, Berg Semsi, close"). A poor boys overhears the two formulas, keeps them in his mind, later opens the mountains and fills his pockets with gold. He becomes rich, takes good care of his family and helps the needy. And when his brother needed money, he asked him for help and secretly followed him to the mountain, discovered how he fetched the money 
from the hiding place in the mountain and about the formulas. Later on, the brother entered the mountain, but forgot the original formula and got caught by the twelve great men. This Grimm's tale is similar to the Fon tale The Hunter's two sons in many aspects. Both tales are about two boys, ghosts or men with magical powers, and a treasure trove. Only the end of the two tales is different: in the Fon tale, both brothers are killed by the ghosts Aziza, while in the Grimm's tale only one brother meets this evil fate. In addition, there is an assumption that the mountain of the Grimm's tale contains not only money and gold, but other precious things such as pearls and precious stones.

Termite mounds and mountains as treasure troves are not only present in African and European fairy tales. In the orientalist tales of Ali Baba and the Forty Thieves (Weil 2013, pp. 1186 -1219; German version), a rock plays such a role: A poor woodcutter named Ali Baba beholds forty thieves and their leader opening and closing a rock respectively with the help of the formulas "Sesame, open" and "Sesame, close". Ali Baba, who is sitting in a tree the time, eavesdrops on the formulas and enters the rock after the thieves have ridden away. He finds food, bales of merchandise, silks and brocades, carpets and especially much gold and silver, some of which is piled up in heaps and some in some in leather bags. He takes the gold and returns home. As the story progresses, the thieves take revenge on the lucky treasure finder. With the riches that are found in the rock in this orientalist tale are stolen goods in contrast to those in the Fon and the Grimm's tales.

In other fairy tales by the Fon and the Grimm is the similarity the suffering of the characters who get the help of the animals and become rich and powerful. In Die zwei Zwillingsbrüder (Eng.: "The two twin Brothers"; Lanmadousselo 2021, pp. 278-285), for example, Zinsou stabs out both the eyes of his twin brothers Sagbo and the latter goes blind. Because of his blindness, Sagbo limps up to a tree. Then he sits down under it and starts asking passers-by for alms. Just at that time, birds sit on the tree he is under and reveal the remedy of blindness to him. Sagbo implements the message of the birds and cures his blindness. Thanks to the same revelation, Sagbo heals a sick king in the continuation of the tale and is himself appointing king. In the Grimm's fairy tale "Die Krähen" (Eng.: "The crows"; Children's and Household tale: appendix 20) two friends gouge out a soldier's two eyes and rob him of his money. The soldier, now blind, is tied to a beam. Then he begins to pray to God. As he prays to God, he hears three crows, who have sat on the beam, saying how the dew from heaven that day can cure the blindness. In addition, they reveal the ashes of a toad found in a certain pond would cure a sick king's daughter if she drinks them with water. The soldier follows the instructions of the crows and heals from the blindness. He also succeeds in curing a sick king's daughter and demand her as his wife. 


\section{The problem of the authenticity of the fairy tales of the Fon from Benin}

As indicated above, Jacob and Wilhelm Grimm had dealt with a similar question and had come to the conclusion that the Indo-European people shared many similar fairy tales. If both brothers initially attributed the fairy tales to the Germanic people, their position had changed after having access to foreign fairy tales. They first considered the migration of fairy tales from one country to another to be possible, but Jacob Grimm later contradicted this in the preface to Felix Liebrecht's edition to of the Pentamerone:

Man lasse fahren den wahn, sie seien an irgend einer begünstigten stelle aufgewachsen, und von da erst auf äusserlich nachweisbarem weg oder pfad in die ferne getragen worden. Das ist jetzt schon durch sorgfältige sammlungen, nicht nur in allen strichen Deutschlands, sondern auch des Nordens und des Südens, widerlegt [...] (Basile1846, S. IX.).

(Eng.: „Let us abandon the delusion that they grew up in some favoured place, and from there they carried far away by an externally verifiable path. This has already been disproved by careful collections, not only in all parts of Germany, but also in the north and south $[\ldots])$.

The various position of the Grimm on the question of the origin of fairy tales form the basis of many theories, including the theory of migration and polygenesis.

According to the migration theory, the place of the origin of fairy tales goes back to India. There, the first fairy tales "aus einem der ersten nachchristlichen Jahrhunderte“ (Eng.: „From one of the first post-Christian Centuries"; Bausinger 1968, p. 30) were recorded under the titel Pantschatantra. The Göttingen sanskrit reseacher Theodor Benfey, one of the Pioneers of this theory, formulated the thesis that the Pantschatantra spread from India via Europe all over the world (cf. Aarne 1913, p. 4). At the centre of this dissemination are fairy tales and their narratives materials (cf. Pöge-Alder 2007, pp. 81-82).

The theory of polygenesis, an anthropological approach, refutes the dissemination of fairy tales through migration and literature and attributes the origin and spread of fairy tales to polygenesis. The supporters of this theory, whose pioneers are the English scholars Edward Burnett Tylor and Andrew Lang, postulate that the fairy tales did not spread from one country to another, but rather originated in different countries or in spatially and temporally distant regions independently from each other. They further justify this theory by the same basic conditions of the people or by the same mental dispositions of all people (cf. Aarne 1913, p. $6)$. 
From the perspective of this methodological framework, it is difficult to argue that the West African fairy tales and especially the Fon tales are influenced by foreign fairy tales (Asian and European).

The former kingdom Danxomè, today Benin, was, like many West African countries, scriptless. In the absence of writings and books, the main mean of communication was orality. Literature existed only orally, and it was and still is very much alive in the rural areas. Oral genres such as panegyrics, proverbs, myths, folk songs and fairy tales were and still are very important. Only after the spread of the Catholic faith in the year 1861 (cf. Alladaye 2003, p. 28) and the accompanying introduction of schooling and education for the native West Africans, the way was paved for the first field research. The Africanist Wilhelm Möhlig points to the period in question by writing:

Kurz vor der Jahrhundertwende [1900] entstand eine auch heute noch lebendige Forschungsrichtung, deren Ziel es ist, auf der Grundlage der afrikanischen Volksliteraturen in die Geistes der Afrikaner vorzudringen. (Möhlig 1988, p. 332)

(Eng.: Shortly before the turn of the century [1900], a line of research emerged that is still alive today, the aim of which is to penetrate the intellectual world of Africans on the basis of African folk literatures).

Missionaries, representatives of the colonial powers, teachers and researchers began to collect African fairy tales:

Sie sind geborene Erzähler, meine afrikanischen Freunde, und Märchen kennen sie alle. Es ist nur schwer, den Fluß der lebendigen Rede, der noch durch eine lebhafte Gebärdensprache unterstützt wird, in der Schrift festzuhalten. Fängt man an zu schreiben, dann ermüdet der Erzähler leicht und begnügt sich damit nur kurz den Inhalt wiederzugeben. Darum erscheint manches Märchen hier zu knapp in seiner Form. Als ein Muster afrikanischer Freude an der Breite mag aber das erste Märchen vom Sultan Darai dienen. Aus mancherlei Quellen stammen diese Märchen - aus Sammlungen volkstümlicher Stoffe, Grammatiken, Wörterbüchern, Zeitschriften. Die sie aufzeichneten, waren zumeist Missionare, - auch Gelehrte, wie Dr. Büttner und Professor Westermann gehören dazu - aber auch Lehrer, Beamte, Sprachforscher haben an der Aufzeichnung der Märchen mitgearbeitet, auch Frauen. (Meinhof 1921, p. 3)

(Eng.: „They are born storytellers, my African friends, and they all know fairy tales. It is difficult to capture in writing the flow of their lively speech, which is supported by a lively sign language. When one begins to write, the narrator tires easily and is content with only briefly reproducing the content. That is why some fairy tales are here too 
brief in their form. However, the first tale of Sultan Darai may serve as a model of African joy in breath. These fairy tale come from many sources - from collections of popular materials, grammars, dictionaries, magazines. Those who recorded them were mostly missionaries - scholars such as Dr. Büttner and professor Westermann are also among them - but teachers, civil servants and linguists also worked on recording the fairy tales, including women).

In 1854, the English missionary Sigismund Wilhelm Kölle conducted five years of linguistic research in Sierra Leone, West Africa, during which he recorded proverbs and animal tales of the Kanuri people. He was helped in the translation fairy tales into English by the few educated local people at the time (Cf. Kölle 1854, p. V). Almost a decade later, François Victor-Equilbecq, one of the representatives of the French administration in West Africa, followed Kölle's research. Equilbecq merit lies in the fact he not only collected West African fairy tales, but studied them scientifically (cf. Equilbecq 1913). After him, René Trautmann, who worked as a doctor in the French colonial army, collected many fairy tales in Dahomey at the time, today Benin (cf. Trautmann 1927). Also the German ethnologist and Africa researcher Leo Frobenius, who travelled to Africa many times for his research activities could not resist collecting African fairy tales. The book Atlantis. Volksmärchen und Volksdichtung Afrikas was published from his collecting (Frobenius 1927). In 1948, R. P. Barreau published Contes et légendes du Dahomey, a collection of fairy tales and myths (Barreau 1948). A decade later, 1958, Melville and Frances Herskovits published Dahomean Narrative. A cross-cultural analysis (cf. Herskovits M./ Herskovits F. 1958). The book is about generalities about Beninese narratives, especially collections of fairy tales and myths of the Fon, which are classified thematically.

The motivation of the fieldwork vary according to the concerns of the field researchers. While Kölle and Frobenius, for example, spoke of researching African cultures and literatures, the field research carried out by officials and representatives of the colonial administration had a different objective. In the collection of West African fairy tales, Equilbecq had, for example, the exploration of the psychology, the way of life and the beliefs of West African people:

Pour bien connaître une race humaine, pour apprécier sa mentalité, pour dégager ses procédés de raisonnement, pour comprendre sa vie intellectuelle et morale, il n'est rien de tel que d'étudier son folklore, c'est-à-dire la littérature naïve et sans apprêts issue de l'âme populaire et nous la livrant dans sa nudité primitive. Aussi convient-il d'encourager tous ceux qui, appelés par leurs fonctions à vivre au contact de populations aussi mal connues de nous que le sont encore les Noirs de l'Afrique Occidentale, ont eu la patience et le talent d'écouter parler les indigènes et de recueillir de leur bouche les contes merveilleux ou légendaires, les fables animaux, les apologues 
satiriques qui constituent le fond de la littérature orale de ces peuplades privées de littérature écrite. (Equilbecq 1913, p. II)

(Eng.: "In order to know a human race well, to appreciate its mentality, to understand its intellectual and moral life, there is nothing like studying its folklore, that is to say, the naïve and unadorned literature of the popular soul, which gives it to us in its primitive nakedness. It is therefore appropriate to encourage all those who, called by their duties to live in contact with populations as little known to us as the Blacks of West Africa, have had the patience and talent to listen to the natives and to gather from their mouths the marvellous or legendary tales, the animal fables, the satirical apologues which form the basis of the oral literature of these people deprived of written literature.")

According to the methodological approaches of the aforementioned pioneers of West African fairy tales research, European tales did not spread in West Africa through the contact of Europeans with the West African people. Rather, they confirm the assumption that fairy tales existed before the arrival of missionaries, scholars and traders in West Africa. Maurice Delafosse, one the representatives of the French colonial power in West Africa, drew attention to this in his preface to Equilbecq's book:

Par tout le continent africain, et notamment dans l'immense région qui s'étend entre le Sahara la forêt équatoriale et que nous appelons communément le Soudan, cette littérature orale fleurit depuis des siècles et elle a acquis, de génération en génération, une richesse et une ampleur d'autant plus considérable que, sauf dans une minorité de musulmans instruits et versés dans la langue arabe, aucune littérature orale n'est venue lui faire concurrence. (Ebd.)

(Eng.: "Throughout the African continent, and particularly in the immense region that stretches between the Sahara and the Equatorial Forest, which we commonly call the Sudan, this oral literature has flourished for centuries and has acquired, generation after generation, a richness and breath that is all the more that, except in a minority of educated Muslims versed in the Arabic language, no oral literature has come to compete with it.")

If one tries to test Delafosse's assumption that there is only a slight probability that West African fairy tales were influenced by Arabic oral literature, one does not come to any meaningful conclusion. The Fon were firmly anchored in their traditions. The first contact with the religious sphere took place with the European Christian missionaries (cf. Alladaye 2003, P. 
28). The Fon regions were not arabised like, for example, the Swahili region on the east coast of Africa. Contact between Asia and the Swahili region has existed since pre-Christian times. Islam and the associated reading and writing in Arabic spread there early on. Even before the turn of the century 1900, reading Arabic writings such as One Thousand and One nights was not uncommon (cf. Schmidt 1999, pp. 190-191).

Nowadays, the context of fairy tale transmission has changed a lot in many African countries and especially in Benin. The country is on its way of modernisation. The ability to read and writing is no longer an exception as it was in pre-colonial times, as more and more people are attending school. The book market is also experiencing a new development. Many foreign books as Les contes de Perrault (Eng.: Perrault's fairy tales; first edition in 1697, cf. Perrault 1797), Les mille et une nuit (Eng.: One Thousand and One nights, Galland 1704), Les contes de l'enfant et du foyer (Eng.: Children's and Household tales, Baudry 1855) have found their way into Beninese library and bookshops. Some fables by the French author La Fontaine such as La poule aux oeufs d'or (Eng.: "The chicken with golden eggs") and Le corbeau et le renard (Eng.: "The raven and the fox") are taught in Beninese primary schools (status: school year 2021-2022). If it can be assumed that the European fairy tales or the Grimm's fairy tales have become popular with some Fon Natives who have completed a school or academic education and may possibly alienate their knowledge of the Fon fairy tales, it must be contrasted with the fact that the foreign fairy tales are very little known in rural areas, which are the stronghold for storytelling. Reasons for this are the high illiteracy rate of the people living in these areas, where the aforementioned Fon fairy tales were recorded.

\section{Conclusion}

The fact that some Fon fairy tales have similarities with European fairy tales does not justify the assumption that the Fon fairy tales are not authentic, especially since these fairy tale variants can be found in other volumes. At the centre of the similarities between fairy tales from different cultures is the human being himself through his mental disposition as a producer of the same or similar fairy tales. 


\section{References}

Aarne, Antti. (1913). Leitfaden der vergleichenden Märchenforschung, Hamina.

Agléwé, Sourou Dieudonné. (2015). Die Frau in beninischen Volksmärchen. Eine Studie zu den Frauenbildern in den Märchen der Volksgruppe Mahi mit Bezug auf die Kinderund Hausmärchen der Brüder Grimm. Diss., Berlin: Wissenschaftlicher Verlag Berlin. Alladayè, Jérôme. (2008). Fresques danxoméennes. Cotonou: Les Éditions du Flamboyant. Basile, Giambattista. (1846). Der Pentamerone oder: Das Märchen aller Märchen. Aus dem Neapolitanischen übertragen von Felix Liebrecht. Nebst einer Vorrede von Jacob Grimm. Bd. 1. Breslau: Max.

Barreau, R. P. (1948). Contes et légendes du Dahomey. Collection Lavigerie. Namur: Grands Lacs.

Baudry, Frederic (édit.). (1855). Contes choisis des frères Grimm. Paris: L. Hachette. Bausinger, Hermann. (1968). Formen der "Volkspoesie“. Berlin: Erich Schmidt Verlag. Equilbecq, François-Victor. (1913). Essai sur la littérature merveilleuse des noirs; suivi de contes indigènes de l'Ouest africain français. Tome premier. Paris: Ernest Leroux, Édite Frobenius, Leo. (1927). Atlantis. Volksmärchen und Volksdichtungen Afrikas. Bd VI. München: Veröffentlichungen des Forschungsinstituts für Kulturmorphologie.

Galland, Antoine (Hrsg.). (1704). Les Milles et une nuit. Contes Arabes. Traduits en Français par Antoine Galland. Nouvelle édition corrigée. Tome I. Paris: Compagnie des Librairies.

Herskovits Melville/Herskovits Frances. (1958). Dahomean Narrative. A cross-cultural Analysis. Evanston: Northwestern University Press.

Kölle, Sigismund Wilhelm. (1854). African native literature, or proverbs, tales, fables, and historical fragments in the Kanuri or Bornu Language. London: Church Missionary House.

Lanmadousselo, M. J. Sewanou. (2021). Umweltethik in beninischen Volksmärchen. Untersucht an den Märchen der Fon-Volksgruppe mit einem Seitenblick auf die Grimm'schen Kinder-und Hausmärchen. Kassel: KUP.

Meinhof, Carl (Hrsg.) (1921). Afrikanische Märchen. Jena: Eugen Diederichs.

Möhlig, J. G. Wilhelm. (1988). Die Erforschung der afrikanischen Oralliteraturen durch deutschsprachige. Gelehrte. Entwicklung und derartiger Stand. In: Möhlig, J. G. W; Jungraithmayr, H; Thiel, J. F. (Hrsg.). Die Oralliteratur in Afrika als Quelle zur Erforschung der traditionellen Kulturen. La littérature orale en Afrique comme source pour la découverte des cultures traditionnelles. Berlin: Dietrich Reimer Verlag, S. 331S. 339.

Perrault, Charles. (1697). Histoire du temps passé. Paris : Claude Baudin.

Pöge-Alder, Kathrin. (2007). Märchenforschung: Theorien, Methoden, Interpretationen. Tübingen: Gunter Narr Verlag.

Rölleke, Heinz (Edit.). (2009). Brüder Grimm Kinder-und Hausmärchen. Ausgabe letzter 
Hand. Mit einem Anhang sämtlicher, nicht in allen Auflagen veröffentlichter Märchen. Stuttgart: Philipp Reclam jun.

Schmidt, Sigrid. (1999). Hänsel und Gretel in Afrika. Märchentexte aus Namibia im internationalen Vergleich. Köln: Rüdiger Köppe Verlag.

Trautmann, René. (1927). La Littérature populaire à la Côte des Esclaves. Paris: Institut d'ethnologie.

Weil, Gustav [translator]. (2013). 1001 Nacht. Vollständige Ausgabe mit über 700 Illustrationen. Band 2. Hamburg: Nikol Verlag.

Wekenon Tokponto, Mensah. (2003). Deutsch-beninische Märchenforschung am Beispiel von Märchen in der Fon-Sprache mit phonetischer Transkription, Studie und Darstellung der Hauptfiguren und Themenvergleich, Universität Bielefeld, Dissertationsarbeit, 1. Aufl. Frankfurt: Peter Lang Verlag.

Wienker-Piepho, Sabine. (2017). „Das Lieblingsmärchen gibt Ihre gesamte Psyche preis“. Retrieved from https://www.deutschlandfunkkultur.de/sabine-wienkerpiepho-ueber-maerchen daslieblingsmaerchen.1008.de.html?dram:article_id $=40$

\section{About the author:}

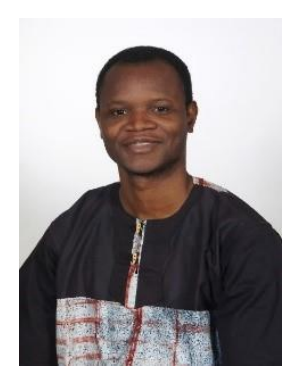

Sewanou J. M. Lanmadousselo was born in Benin (West Africa). He studied intercultural German studies there. He received his PhD from the "Universität Kassel" (Germany) in 2021. He is the author of "Wie die Frauen ihre Busen bekamen. Oraltradierte Märchen der FonVolksgruppe aus Benin" (2018) and "Pourquoi la grenouille ne va pas à quatre pattes. Contes du Bénin" (2018). The topic of his dissertation is: "Umweltethik in beninischen Volksmärchen. Untersucht an der Fon-Volksgruppe mit einem Seitenblick auf die Grimm'schen Kinder-und Hausmärchen." His main areas of focus are: German and African fairy tales research, African Literature, Eco criticism. 